\title{
Recepcja literacka obrony i rzezi Pragi
}

Irena Łossowska 


\section{IRENA ŁOSSOWSKA}

\section{Recepcja literacka obrony i rzezi Pragi}

padek powstania kościuszkowskiego rozpoczął się znacznie wcześniej niż tragiczny ranek 4 listopada 1794 roku na Pradze. Przegrana bitwa pod Maciejowicami (10 października) i wzięcie Kościuszki do niewoli zachwiało wiarę w pomyślność insurekcji. Współczesny pamiętnikarz pisze: „... gdy zwycięski wódz rosyjski Fersen doniósł królowi polskiemu, że pojmał Kościuszkę, cała Warszawa tonęła we łzach i lamentach [...] kobiety suknie na sobie darły [...] o ziemię się rzucały. Pospólstwo warszawskie w pierwszym impecie żalu [...] wysforowało się do 20 tysięcy pod Maciejowice na odbicie Kościuszki i już było za Jeziorną 3 mile od Warszawy, ale umiarkowańsza w pasjach Rada słała za nimi z perswazjami [...]"1. Historyk dodaje również, że miasto ogarnęła niewypowiedziana boleść i rozpacz, że nastąpiły dni „zupełnego upadku ducha"2. W takiej atmosferze postanowiono stoczyć walkę z nadciągającymi wojskami Suworowa. Badacz wojskowości ${ }^{3} z$ perspektywy dwustu lat twierdzi, że klęska praska była przesądzona z powodu błędnych decyzji naczelnego wodza Tomasza Wawrzeckiego, który wbrew sugestiom generałów nie ściągnął wszystkich odwodów wojskowych znad Bzury, Narwi i Pilicy, liczących ponad dwadzieścia trzy tysiące wyszkolonego żołnierza. Pragi broniła trzynastotysięczna armia polska, wspomagana źle uzbrojonym mieszczaństwem. Wróg miał przewagę dwukrotną. Wygrywając rozprawił się okrutnie z walczącymi i cywilną ludnością. Bezprzykładne mordowanie dzieci, starców, kobiet i duchowieństwa określano w tradycji ustnej i literaturze mianem rzezi Pragi. Zginęło wówczas około ośmiu tysięcy ludzi. Na długie lata Suworow i Praga stały się synonimem tragedii narodowej, która pogrzebała ideę niepodległości.

Czy ślady tamtych dramatycznych dni i ostatnich godzin odnajdujemy w twórczości literackiej? Wśród drukowanych znalezisk literatury okolicznościowej z czasów insurekcji jest niewiele tekstów poświęconych obronie i rzezi Pragi. Próbując odtworzyć nastroje i emocje wówczas panujące sięgnęliśmy do utworów i zacho-

1 J. Kitowicz, Pamiętniki czyli historia polska, tekst opracowała i wstępem poprzedziła P. Matuszewska, komentarz Z. Lewinówna, Warszawa 1971, s. 612.

2 H. Mościcki, Generał Jasiński i powstanie kościuszkowskie, Warszawa 1917, s. 334.

${ }^{3}$ A. Rzepniewski, Zmierzch Insurekcji - szturm Pragi (maszynopis przeznaczony do druku). 
wanych fragmentów, które według badaczy miały towarzyszyć praskim wypadkom. Wydaje się, że zasadne będzie wprowadzenie do omawianego bloku poetyckiego także tych tekstów, które powstały w latach 1795-1797. Są to utwory chronologicznie najbliższe, a ponadto wyrastają z tych samych doświadczeń, przeżyć i realiów. Do ich twórców należeli bowiem autorzy, będący uczestnikami i świadkami powstania. Natomiast późniejsze reminiscencje z motywami i wątkami dotyczącymi rzezi Pragi, poetyckie opisy tamtych dni - których mnóstwo powstało w całym XIX i XX wieku, głównie przy okazajach rocznicowych - stanowią materiał historycznoliteracki i jako takie powinny doczekać się monograficznego opracowania. Wciąż jeszcze literatura okolicznościowa pozostaje na uboczu refleksji naukowej.

Warto jednakże zasygnalizować, że wypadki praskie odżyły w przeróżnych wersjach i mutacjach $w$ formie rozbudowanych obrazów poetyckich lub znaków-symboli u bardzo wielu poetów, żeby wymienić najbardziej reprezentatywne nazwiska Mickiewicza, Słowackiego, Cypriana Godebskiego, Antoniego Goreckiego, Marii Konopnickiej. W prozie zbeletryzowanej wśród dużej ilości utworów na uwagę zasługuje piękna i wzruszająca powieść historyczna józefa lgnacego Kraszewskiego W Warszawie 1794 roku (1873) oraz powieść Wacława Berenta Nurt (1934), w której słowa-klucze takie jak Praga, Suworow uzyskały juz rangę symbolu. A w konkretnej sytuacji historyczno-politycznej miały stanowić złowróżbny kontekst dia polskiego żołnierza na ziemi włoskiej.

Zachowane druki w całości lub we fragmentach, traktujące o obronie i rzezi Pragi przywołują m.in. Henryk Mościcki ${ }^{4}$, Juliusz Nowak-Dłużewski ${ }^{5}$, Roman Kaleta ${ }^{6}$, Lucjan Cieślak. Na temat stanu badań wypowiadają się we wstępach i obszerniejszych pracach wymienieni badacze. $Z$ istotniejszych ogólniejszych rozpraw należy wymienić, świeżo wznowiony w 1994 roku, syntetyczny szkic Zdzisława Libery Powstanie Kościuszkowskie w literaturze polskiej ${ }^{8}$.

Wiadomo, że insurekcja zrodziła ponad sto okolicznościowych utworów poetyckich. Znakomitą ich większość stanowiły pieśni, hymny, pobudki, marsylianki o proweniencji francuskiej. Dużo tekstów było związanych z osobą Naczelnika Tadeusza Kościuszki. Wiersze o innej problematyce wyrażały przeważnie radość i entuzjazm z powodu pomyślnego rozwoju wypadków. Najpełniejszy ich zestaw obejmuje wspomniana antologia sporządzona przez Nowaka-Dłużewskiego. Wśród różnych wierszy pokaźną grupę stanowi liryka satyryczna, która upamiętniała znane wypadki samosądów ludowych. Warto zaznaczyć, że terminu „liryka satyryczna"

\footnotetext{
H. Mościcki, op. cit. s. 408.

5 Poezja powstania kościuszkowskiego, wstęp i objaśnienia J. Nowak-Dłużewski, Kielce 1946. s. 94-98.

R. Kaleta, Wiersze na cześć generała Jakuba Jasińskiego, w: „Rocznik Zakładu Narodowego im. Ossolińskich", 1957, t. 5, s. 437-453.

${ }^{7}$ L. Cieślak, Pieśn polityczna Oświecenia. Dokument mało znany, Łódż 1991, s. 185.

${ }^{8}$ Z. Libera, Powstanie kościuszkowskie w literaturze polskiej, w: Rozważania o wieku tolerancji rozumu i gustu, Warszawa 1994. Tekst pierwotny ogłoszony w: „Przegląd Humanistyczny” 1968, nr 2 .
} 
w odniesieniu do różnego rodzaju nagrobków użył po raz pierwszy Nowak-Dłużewski ${ }^{9}$. Natomiast klęski i przegrane bitwy (Szczekociny $-6 \mathrm{VI}$, Chełm $-8 \mathrm{VI}$, Kraków - $15 \mathrm{VI}$ ) może $z$ wyjątkiem Maciejowic ${ }^{10}$ wywoływały niewielki rezonans poetycki.

Podobne zjawisko przemilczania, informowania z opóźnieniem o niepowodzeniach powstania da się zauważyć w ówczesnych periodykach. Analogie między okolicznościową poezją a ówczesną prasą nasuwają dość ciekawe spostrzeżenia. Wiadomo, że jedna i druga forma przekazu nie tylko odzwierciedlała aktualne nastroje, ale w zamierzeniu twórców miała stymulować i wspomagać bieg powstańczych wydarzeń. W pierwszym okresie insurekcyjnym okolicznościowa liryka zdecydowanie wyprzedzała prasę. Wierniej oddawała zmienność nastrojów, śmielej i odważniej ujawniała radykalizację ulicy, konsekwentniej demaskowała społeczne podziały i formułowała antydespotyczne hasła. Po kolejnych przegranych, od czerwca, a szczególnie po klęsce maciejowickiej, sytuacja ulega odwróceniu. Poezja okolicznościowa powoli zamiera, liryki, które powstają, mają charakter defetystyczny i oddają atmosferę zwątpienia, bezradności i rozpaczy. Natomiast periodyki, po chwilowym szoku, który przeżywają wraz z mieszkańcami stolicy i Polski, bardzo aktywnie wspierają poczynania Rady Najwyższej Narodowej i nowego naczelnika Tomasza Wawrzeckiego. Ożywienie i chęć współuczestniczenia w ponownym poderwaniu mieszkańców Warszawy i wojska do walki nie trwały jednak długo. Ostateczny upadek powstania po zdobyciu Pragi i kapitulacja lewobrzeżnej Warszawy kończą heroiczny okres. Poezja okolicznościowa umiera śmiercią naturalną, kiedy brakuje impulsu i źródła natchnienia. Periodyki zaś nieco dłużej utrzymywały funkcję propagandową i agitacyjną ${ }^{11}$.

Jak wspomniano, po rzezi Pragi muza prawie umilkła. Bardzo sugestywnie pisze o tym zjawisku Józef Kallenbach we wstępie do Barda polskiego Adama Jerzego Czartoryskiego: „Upadkowi Polski w końcu XVIII wieku towarzyszyło u nas milczenie zgrozy: poezja oniemiała. Uosobieniem jej Kniaźnin, obłąkanym wzrokiem w milczeniu na kompas patrzący, jakby lepszych dni po Maciejowicach dożyć pragnął. Jeden jedyny ze starszych Karpiński prostą uczciwą ręką dotknął prawdziwej struny patriotycznego bólu w Żalach Sarmaty"12.

$W$ istocie współczesnych utworów poetyckich - jak wspomnieliśmy - jest bardzo mało. Zatrzymam się przy kilku, które - wydaje się - są reprezentatywne dla aktualnych nastrojów i formułują ogólniejsze refleksje. Mamy na myśli 1. Pieśn przy sypaniu okopów na Pradze, 2. Pieśń w czasie dobycia Pragi, 3. Duma o wyrżnięciu Pragi oraz 4. wiersz o inc.: Nasz Kościuszko sławny był... Wszystkie wymienione teksty mają charakter anonimowy. Obok liryków można odnotować prozaiczne, nieco tendencyjne opowiadanie bliżej nieznanego, naocznego świad-

\footnotetext{
${ }^{9}$ J. Nowak-Dłużewski, op. cit. s. XLI - XLVI.

${ }^{10}$ Bitwa pod Maciejowicami $10 \times 1794$ r. Żale pomaciejowickie, wybór tekstów historycznych i literackich, opracowanie i noty edytorskie A. Woltanowski, wstęp T. Rawski i A. Woltanowski, Białystok 1994.

"Por. I. Łossowska, „Korespondent Warszawski i Zagraniczny" w latach 1792-1796. (Zarys monograficzny), Warszawa 1969.

${ }^{12}$ A. J. Czartoryski, Bard polski 1795, wydał i wstępem poprzedził J. Kallenbach, Brody 1912, s. 3.
} 
ka Zbyszewskiego pt. O kapitulacji Warszawy w roku $1794^{13}$. Ów kanon powiększamy o utwory, sąsiadujące chronologicznie z wydarzeniami praskimi, co już zostało nadmienione. Do nich należy zaliczyć wspomnianego Barda polskiego Czartoryskiego z 1795 roku (wersja pierwotna), Nagrobek Jakubowi Jasińskiemu Jenerałowi Rajmunda Korsaka z 1795 roku, Treny na rozbiór Polski Józefa Morelowskiego z 1795 roku, wymienione Żale Sarmaty nad grobem Zygmunta Augusta... Karpińskiego z 1797 lub 1805 roku oraz Smutki Hugona Kołlątaja (elegie i fragmenty prozaiczne) pisane w więzieniu od 1795 do 1796 roku.

Wszystkie te utwory doczekały się obszernych omówień. Zwrócimy uwagę tylko na niektóre. Wypada wspomnieć o Kallenbachu, autorze trzeciej edycji Barda polskiego z 1912 roku, w której obok filologicznego wstępu znajdujemy wersję pierwotną oraz poprawioną i rozszerzona, paryską z 1840 roku z przedmową Juliana Ursyna Niemcewicza. Należy wymienić Kazimierza Władysława Wójcickiego ${ }^{14}$, który pierwszy dokonał identyfikacji anonimowego wiersza Nagrobek Jasińskiemu... i przypisał do Korsakowi, co dodatkowo potwierdził S. Jabłoński i Mościcki w znanej monografii o Jasińskim ${ }^{15}$ oraz Kaleta ${ }^{16}$. O Trenach... Morelowskiego informuje w ujęciu monograficznym Elżbieta Aleksandrowska ${ }^{17}$, natomiast poezje więzienne Kołłątaja omówił w obszernej pracy Piotr Żbikowski ${ }^{18}$.

Pierwsza niewielka grupa liryków jest genetycznie związana z listopadem 1794. Wyjątek stanowi wcześniejsza Pieśń przy sypaniu okopów..., która powstała jako odpowiedź na apel prezydenta Ignacego Wyssogoty Zakrzewskiego ${ }^{19}$ o wznowienie prac nad oszańcowaniem prawobrzeżnej Warszawy. Jak wiadomo - roboty fortyfikacyjne rozpoczęte od czerwca toczyły się leniwie. Kontynuowano je w następnych miesiącach, głównie siłami miejscowego chłopstwa. Ale perswazje na niewiele się przydawały. Również nie odniosły skutku patriotyczne wezwania anonimowego poety $w$ wymienionym liryku. Prace ukończono $w$ ostatnich dniach powstania (podobno niesolidnie) siłami mieszkańców, ale odpłatnie. Dystych rozpoczynający Pieśń... w słowach:

Kto na odgłos ojczyzny ziewa

Niech sobie w domu spoczywa ${ }^{20}$.

dowodzi, że minął dawny entuzjazm, kiedy ze śpiewem i muzyką mieszkańcy Warszawy sypali szańce w obronie przed Prusakami.

Pozostałe liryki: Pieśń w czasie dobycia Pragi, Duma o wyrżnięciu Pragi oraz wiersz poświęcony Kościuszce łączy wspólna dramatyczna wymowa o ostatniej

${ }^{13}$ Opowiadanie Zbyszewskiego o kapitulacji Warszawy w 1794 roku, Kraków 1894.

${ }^{14}$ K. W. Wójcicki, wstęp do: Pisma Jakuba Jasińskiego generała inżynierii, Kraków 1869, s. III.

${ }^{15}$ S. Jabłoński, wstęp do: List Barnaweta do Trumana..., Warszawa 1816. H. Mościcki, op. cit. s. 413 .

${ }^{16}$ R. Kaleta, op. cit. s. 442-447, por. także K. Maksimowicz, Rajmund Korsak, w: Pisarze polskiego oświecenia pod redakcją Z. Golińskiego i T. Kostkiewiczowej, Warszawa 1994, t. 2. s. 753.

${ }_{17}$ E. Aleksandrowska, Wiersze Józefa Morelowskiego, Wrocław 1983.

${ }^{18}$ P. Żbikowski, Poezje więzienne Hugona Kołtątaja, Wrocław 1993.

${ }^{19}$ L. Cieślak, op. cit. S. 184.

${ }^{20} \mathrm{lbidem}, \mathrm{s} .185$. 
klęsce. Aie w Pieśni w czasie dobycia Pragi, z której dochowały się tylko fragmenty, występują nowe, dotąd nie spotykane akcenty i pada jeden z najcięższych zarzutów: posądzenie o tchórzostwo i zdradę. Oskarżenie sformułowane - jak się wydaje - przez prostego żołnierza jest świadectwem bólu i wzburzenia. Wzmiankowany fragment brzmi następująco:

W okopach mężny stał obywatel
Głodem i nędzą strudzony,
Generał spijał dobry muszkatel
Za krew swych braci kupiony.
A gdy dźwięk rubli Zając usłyszał,
Pierzchał z okopów zdradliwie,
Wawrzecki za nim czem prędzej dyszał²1.

Historia - jak wiadomo - nie potwierdziła zdrady Józefa Zajączka, czołowego jakobina insurekcji. Zarzuca mu jedynie brak talentów dowódczych. Również o naczelniku Wawrzeckim wieść głosi, że cechowała go skromność, głęboki patriotyzm, uczciwość, choć także nieumiejętności w sztuce dowodzenia. Trudno zresztą nawet po latach wątpić w szczerość słów naczelnika, który 23 października w Odezwie do obywateli mówit: ,... obejmując to miejsce po Tadeuszu Kościuszce mogężli wam co takiego obiecywać po sobie, co by nieodżałowaną stratę Jego Narodowi w jakikolwiek sposób nadgrodzić zdało? Nic bynajmniej... Lecz przynoszę z sobą, bracia, chęć najszczerszą, choć nierównym krokiem wstępowania w ślady Jego, najmocniejszą usilność poświęcania się obronie ojczyzny i stałą wierność w przysiędze być razem z wami wolnemi lub umrzeć"22.

Widoczne przerysowania i pewien hiperbolizm w przytoczonym wierszu da się wytłumaczyć silnym stanem emocjonalnym autora. Poszukiwanie winnego budzi jednocześnie ulgę i zawiera w podtekście nadzieję, że epilog mógłby być inny, gdyby „wodzowie" sprostali wymogom chwili. Motyw nadziei jest stałym powtarzającym się elementem, występuje także w elegijnej Dumie o wyrżnięciu Pragi. Cały utwór jest przeniknięty atmosferą melancholii i smutku. Alegoryczna matka-ojczyzna skarży się na nieszczęścia, jakich doznała od „sprzedajnych synów” i wrogów. Jeremiaszowe żale i jęki wyrażone są epitetami w rodzaju „kraj smutny”, „lud nędzny”, „los okrutny”, „nieszczęsna córka”. Jeśli jednak opisy pobojowiska dowodzą skrajnego pesymizmu, to końcowe zwrotki, mówiące o "garstce ludu wolnego", który nie dał się przekupić, i profetyczne słowa o szukaniu w obcym narodzie chleba i honoru przywołują upragnioną nadzieję. Można ją odnieść do przyszłych legionów i wznowienia walki o kraj.

Jest jeszcze $w$ liryku inny motyw, zupełnie niespotykany w oświeceniowych utworach poetyckich (poza tekstami z czasów konfederacji barskiej), który wiąże się z nadzieją, ale ma odmienny rodowód ideowy. Pobrzmiewają w nim echa pro-

\footnotetext{
${ }^{21}$ H. Mościcki, op. cit. s. 408.

${ }^{22}$ "Korespondent Narodowy i Zagraniczny”, dodatek do $\mathrm{nr} 82$ z 28 X 1794. s. 1985.
} 
widencjalizmu sarmackiego i mesjanistycznych tendencji, które na dobre zadomowią się w literaturze romantycznej. Wyrażone jest mianowicie w utworze przekonanie, że poniesiona ofiara - przelana krew w obronie Pragi - może skrócić gniew Boży i w konsekwencji zrealizuje się nadzieja, w domyśle oswobodzenie. Albo przelana krew - sugeruje anonim jednocześnie - może okazać się kolejną ofiarą na drodze do nadziei. Odpowiednie strofy tekstu brzmią następująco:

\section{Boże, te gniewu Twojego strzały \\ Są najsilniejsze na ludzi, \\ Kraj się w pustynię zamienił cały, \\ Ten cię płacz niechaj pobudzi,
A jeśli jego nikt nie odwróci
W karze niechybnej Twej miary, \\ Weź mię z innymi, to gniew Twój skróci: \\ Należę do tej ofiary ${ }^{23}$.}

Na ogół, poza nielicznymi wyjątkami, liryka z okresu insurekcyjnego nie jest najwyższego lotu. Jeśli chodzi o formę podawczą, przeważa w niej konwencja klasycystyczna, która ujawnia się patetycznym wierszem o charakterze monumentalnym i swoistym dla poetyki typem rytmicznym wiersza, zwykle trzynastozgłoskowcem. Nowością natomiast jest sięganie do wzorca ludowego. Cechuje się on melodyjnością, refrenami, prostą symetrią składniową, ludowym typem rytmicznym (siedmio- lub ośmiozgłoskowiec) oraz konkretną i zwyczajną leksyką. Przykładem może być Pieśń ochotników krakowskich Alojzego Felińskiego lub słynna Śpiewka włościan krakowskich zwana także Pieśnią kosynierów. W omawianych lirykach poetyka klasycystyczna jest także ograniczana. W utworze stosuje się przemienny typ rytmiczny i nie przestrzega się nawet klasycznego, sylabicznego wiersza, np. w cytowanym wyżej fragmencie występuje miara $10+8$. Natomiast w konwencji ludowej jest utrzymany wiersz o Kościuszce. Oto próbka:

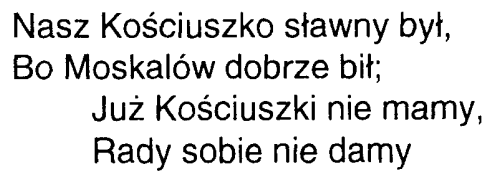

Suwar woła: „Postójcie, Więcej wojska nie psujcie,

Pardon, pardon wołajcie, Broń na ziemię składajcie. ... ${ }^{24}$

\footnotetext{
${ }^{23}$ J. Nowak-Dłużewski, op. cit. s. 96.

${ }^{24}$ Ibidem.
} 
Z walorów merytorycznych ujawniona w wierszu tęsknota za charyzmatyczną osobowością Naczelnika może świadczyć o narodzinach legendy Kościuszki.

Grupa późniejszych liryków z lat 1795-1797, pisana już z pewnym dystansem wobec wydarzeń praskich, ma zabarwienie elegijne i nostalgiczne. Gorycz, smutek, rozczarowanie to powtarzające się motywy. Występuje tu także motyw zdrady, ale zawężony u Kołłątaja w Smutkach do targowiczan i królewskiego obozu. Bohaterami stają się u niego nie tylko Kościuszko i Jasiński, ale również Wawrzecki i Zajączek. Odpowiedni fragment z Elegii na dzień 10 października 1795 r. brzmi następująco:

Darmoś, mężny Zajączku, azardował życie!

Stawiano na twą sławę zewsząd sidła skrycie.

Szczęśliwy! gdy krwią własną, gdy szlachetną blizną

Mogłeś dowieść, że byłeś szczerze za ojczyzną,

I zawstydzić oszczerce, zazdrosne twej cnoty,

Skore do działu chwały, lecz nie do roboty.

Darmoś poległ, Jasiński, darmo inni legli!

Poczciwych nikczemnicy natychmiast odbiegli.

Wawrzecki, próżnoś wzywał wielu w owej sprawie,

Nikt więcej nie chciał stanąć przy tobie w Warszawie! ${ }^{25}$

Apologią tylko jednej osoby jest piękny wiersz Korsaka o bohaterskim Jasińskim. Natomiast w Trenach Morelowskiego po raz pierwszy pada pytanie, czy zbiorowość pozbawiona bytu państwowego oraz symboli narodowych może być nazwana mianem Polaków ${ }^{26}$. W tak postawionym zagadnieniu można dostrzec załamywanie się oświeceniowego pojęcia patriotyzmu. Ale cały cykl, na który składa się trzynaście trenów, jednakże sugeruje, że o integralności narodowej decyduje świadomość i przeżycie jednostki oraz znajomość historycznej tradycji. To one świadczą o sile i świetności narodu' ${ }^{27}$. Warto zauważyć, że Morelowski formułuje niemal programowe założenia Towarzystwa Przyjaciół Nauk, które powołane do życia w 1800 roku postulowało kultywowanie tradycji i języka dla zachowania odrębności narodowej. Natomiast Bard polski Czartoryskiego niesie zapowiedź - używając określenia Kallenbacha ${ }^{28}$ - uczuć, tonów przejmujących i pomysłów, które rozwiną się w patriotycznej poezji romantycznej. Występują bowiem w utworze wszystkie pierwiastki poezji narodowej, jak miłość ojczyzny, żal i ból po jej stracie, nienawiść do wroga, rezygnacja chrześcijańska i nadzieja. Kallenbach jednocześnie przeprowadza bardzo ciekawe paralelne zestawienie myśli Czartoryskiego z przesłaniami, które występują u różnych poetów romantycznych. Badacz odnajduje

${ }^{25}$ H. Kołlątaj, Smutki, wyd. I. Chrzanowski, Warszawa 1909 (odbitka), s. 6.

${ }^{26}$ Por. T. Kostkiewiczowa, Klasycyzm, sentymentalizm, rokoko. Szkice o prądach literackich polskiego oświecenia, Warszawa 1975, s. 256.

${ }^{27}$ Ibidem, s. 257.

$28 \mathrm{~J}$. Kallenbach, op. cit. s. 13 i 14. 
analogiczne motywy Barda w Improwizacji Mickiewicza, w Panu Tadeuszu, w Dziadach części III, w Pieśniach Janusza Wincentego Pola, w utworach Brodzińskiego, Słowackiego i Krasińskiego. Ta wspólnota wątków i motywów poetyckich z różnych okresów literackich najlepiej świadczy o umowności i konwencjonalności cezur, przedziałów i innych barier formalno-estetycznych. Sprawy ważne i wielkie problemy łączy zawsze tożsamość ideowa i wymiar ponadczasowy.

Omawiana poezja okolicznościowa z całego okresu insurekcyjnego z niewielkimi wyjątkami wyszła spod pióra poetów minorum gentium. Tworzona na bieżąco i w wyjątkowych rewolucyjnych czasach ulegała ulotności i dochowała się do naszych czasów okaleczona i niepełna. To jednakże, co zdołało się uratować z późniejszej zawieruchy wojennej dowodzi, że podejmowała ona żywe problemy swojej rzeczywistości, że tkwiła głęboko w nurcie poezji narodowo-wyzwoleńczej, że kontynuowała rodzime tradycje, a często antycypowała tendencje nadchodzących czasów. Nawet wówczas, kiedy sięgała do wzorów obcych, zawsze nasycała zdobycze formalne polską, współczesną treścią. 